\title{
Effect of Calculation of Cost of Production on Selling Price of Products Manufacturing Companies in Papua (Case Study CV. Sagita Grafika)
}

\author{
Mugiati, Bosta Sihombing \\ University of Science and Technology Jayapura, Indonesia \\ a.mugiati@yahoo.com
}

\begin{abstract}
This study aims to determine how the effect of calculating the cost of an order made by the company and the method of calculation of full costing of the product selling price fixing mold. The data used is primary data, order data produced in the period from January 2013 to December 2013, the secondary data obtained from interviews and literature. From these results it can be seen that CV. Sagita Grafika calculate the cost of the product by using the order cost method that produces cost price and the selling price that is incompatible with existing theory, in which the charging of indirect labor and overhead costs shared equally on all types of orders in the amount of Rp. 11.78825 million for indirect labor costs and Rp. 3.1243 million for overhead costs so that volume orders will bear fewer overhead costs equal to the volume of orders more. By using a full costing analysis generated calculation method that the volume of orders that more will earn imposition overhead costs more, because in this calculation loading overhead costs charged by direct labor hours incurred for each order. So that orders with a total volume that many will use a lot of labor hours and vice versa. So in this study that most large orders received charging overhead is the order BS-02 Rp. $31,115,590.92$ and most orders received little overhead loading is KK-01 orders in the amount of Rp. 2,208,622.32. Results of a comparison between the cost of the company with the full costing is the total cost of less Rp. 27,499,540.57, the selling price of Rp. 5,866,543.90, while the larger profit generated by using the full costing method that is Rp. 21,632,996.67
\end{abstract}

Keyword: Cost of the order, full costing, product selling prices

\section{Introduction}

The company's success depends on the ability of management in making decisions for the management of a business, whether it is a company with a large-scale, medium and small needed a good management, so that operations can be run effectively and efficiently. In order for a company's operations can run well, then management requires reliable information as a basis for decision making. According to Mulyadi (2001) to increase the profit, a company can do it three ways, the first way to increase the sales volume, this way is not at risk, but it is not easy to do, because of competition with other companies that producing similar goods. The second way to increase the selling price, this action can indeed increase profits, but in the conditions of competition today, the company is not easy to raise prices because it may because consumers run into competitors' products that have lower prices with the same quality product. The third way is to reduce the cost of production in an efficient and control components of the costs, so the production cost can be minimized. Uncontrolled production costs will cause the cost is too high, which in turn will reduce the competitiveness of products and ultimately may reduce earnings. As in other areas in Indonesia, Papua also competition is getting tight, although still in the developing stages, when compared with other major cities in Indonesia. Therefore, one of the strategies that must be done by entrepreneurs, especially a company engaged in the processing of raw materials into finished goods in order to obtain competition is to reduce the cost of production followed by a decrease in selling prices in the market.

According to Mulyadi (2005) cost is a sacrifice that must be issued by the company to manufacture or produce goods and services. These costs are referred to as cost of production. So that management can use cost-efficient, it requires reliable cost information. Determining the cost of production is very important to remember the benefits of the cost of production information are to determine the selling price of products that will be presented in the balance sheet. Issues regarding the cost of production are generally rooted in the lack of good or even the absence of a proper accounting recording process carried out by the company. 
Determining the cost of production becomes a problem that must be made by the company to provide the proper determination of the selling price so as to produce the optimal profit. Cost of production is crucial company's income. Thus, if the company or any less thorough in determining the cost of production, resulting in an error in determining the income obtained by the company. Given the importance of the cost of production that requires precision and accuracy, especially in the face of current competition are spurring companies that compete with one another, to produce similar or substitute products. According to Mulyadi (2004) the function of the cost of production in the company based on order and mass production, is to determine the selling price, to monitor the realization of the production costs, calculate profit / loss gross particular period and determine the cost of inventories of finished products and products in process are presented in the balance sheet. In determining the cost of production, information is needed by the company is information on raw material costs, labor costs, and factory overhead costs.

\section{Literature Review}

According to Hansen and Mowen (2006), Cost of production is the amount of cost of goods that were completed during the period. Costs are only charged to the items resolved is the cost of production of direct materials, direct labor and overhead costs. According to Mulyadi (2007: 10) the cost of production or the socalled cost of goods is pengobanan economic resources is measured in units of money that has occurred or is likely to occur to generate income. Order cost method, the production cost of collection methods applied to companies that produce products on the basis of orders (Mardiasmo, 1994: 27). Process cost method is a method of collecting the cost of production through the production department or the center of liability costs, which are generally applied to companies that produce products in mass (Mardiasmo, 1994: 90). Selling price is the amount of money or goods needed to get some goods or services. The company has always set the price of their products with the hope that the products sold well and earn maximum profit. According to Hansen and Mowen (2003) which been translated by the selling price is the monetary amount charged by a business unit to the buyer or customer for goods or services sold or delivered. According to Mulyadi (2001) Selling Price in principle should be able to cover the full cost plus a reasonable profit, or sales price equal to the cost of production plus a mark-up. According to Supriyono (2001), the selling price is the monetary amount charged by a business unit to the buyer or customer for goods or services sold or delivered. From the above definition can be concluded that the sale price is the amount of expenses incurred by the company to produce a good or service plus a percentage of the desired profit company, because it is to achieve the desired profit by the company one of the ways in which to attract customers is by way of determining the right price for the products sold. The right price is the price in accordance with the product quality of goods, and the price can give satisfaction to the consumer.

\section{Methodology}

Kerangka Konseptual: Adapun kerangka pemikiran dalam penelitian ini adalah sebagai berikut :

Gambar: Conceptual Framework, The framework in this study are as follows:

Figure 1: Conceptual Framework

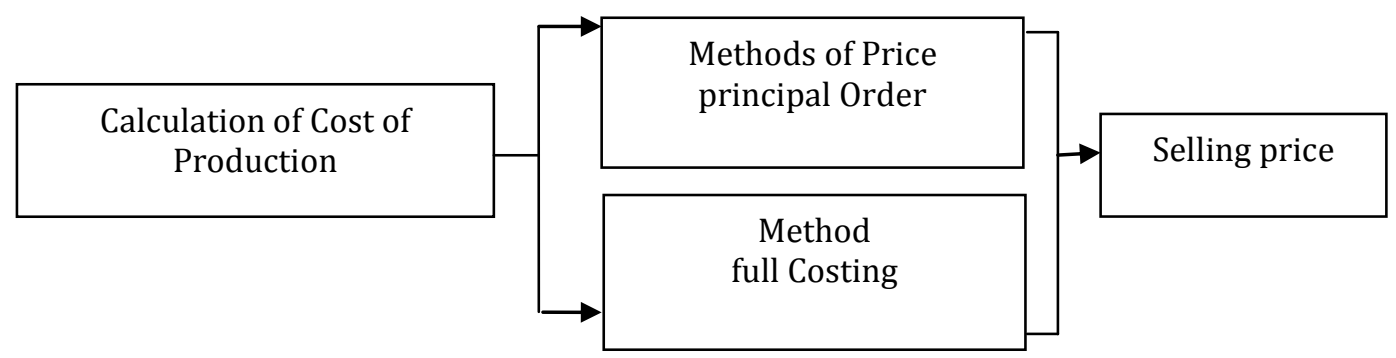

Data source: Reasoning Authors, 2014

The analysis of the data used to answer the above problems is the method of order cost upfront (Job Order Method) is the method of determining the cost of products where the production costs are collected 
(accumulated) for a particular product, and the cost of production per unit is calculated by dividing the total cost of production for these orders by the number of product units in respective orders (Witjaksono, 2006: 37).

\section{Results and Discussion}

Comparison between the Cost Method Order Company with Full Costing Method: From the calculation above shows that there are differences between the calculation of the cost of an order made by the company with the full costing method calculation. In the calculation of the distribution company overhead costs are not consistent with the theory that there is to divide equally to each order, regardless of volume pesanan.hal much or at least this would be detrimental to the volume of orders sedikt and profitable for the buyer that the volume of orders in large quantities. While the full costing method of calculating overhead charges imposed by direct labor hours so that it can be seen that the orders to spend hours of direct labor are more than loading overhead will also be more and vice versa. Here is a comparison table of cost price and the selling price generated by calculating the cost of an order made by the company with the results of calculations using the full costing method:

Table 1: Comparison Between Methods of Calculation of Cost of Company Orders Calculation Method with Full Costing

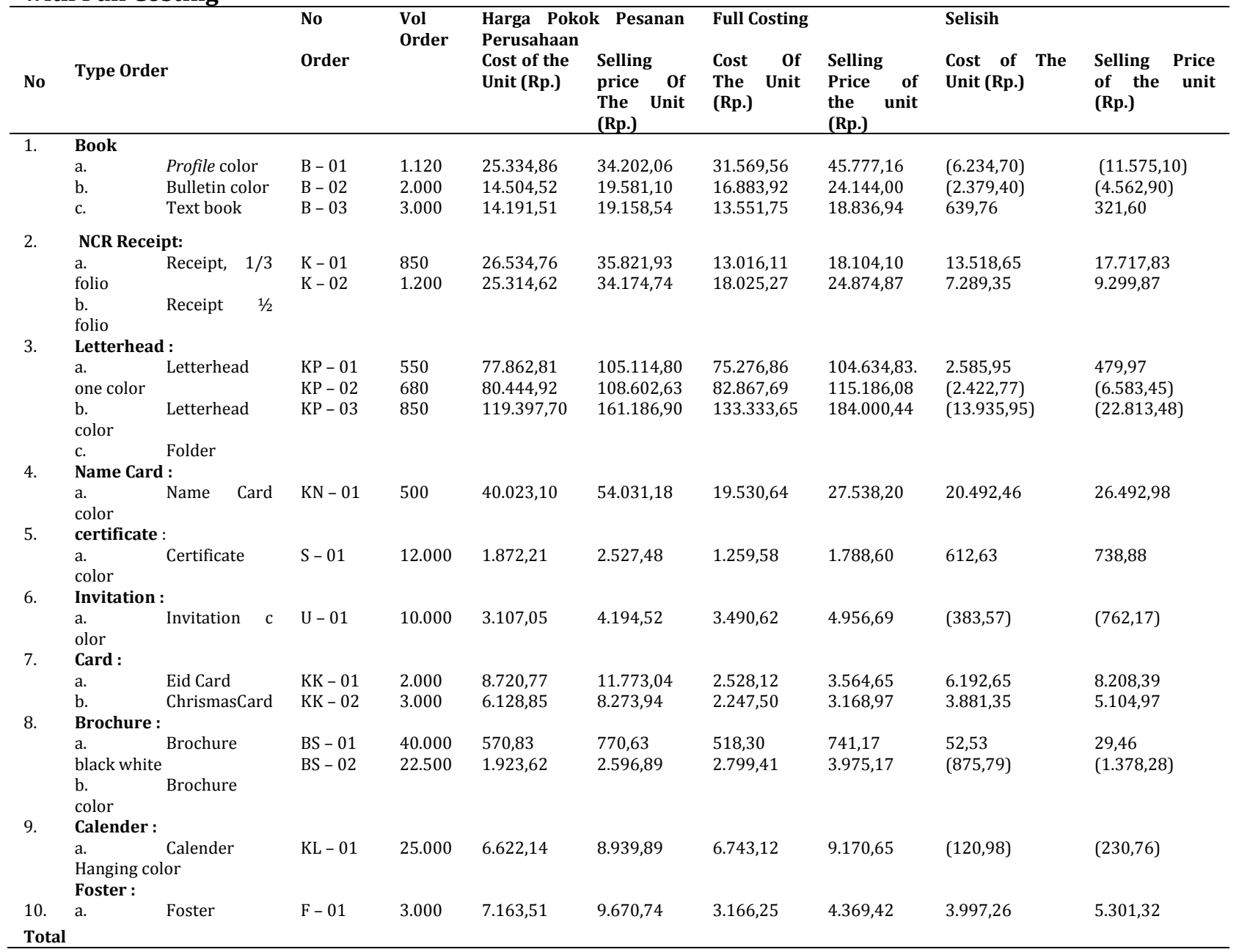

Source: Secondary Data that have been processed, 2014

From the table above shows that the calculation with the full costing method to order B-01, B-02, KP-02, KP03, U-01, BS-02 and KL-01 cost price and the selling price resulting higher so visible datable difference minus 
the comparison result. To reserve B-01 difference (Rp. 6234.70) and (11575.10) Order B-02 difference (Rp. 2379.40) and (Rp. 4562.90), KP-02 order difference (Rp. 2,422, 77) and Rp 6583.45), KP-03 order difference (Rp. 13935.95) and (Rp. 22813.4), U-01 order difference (Rp.383,57) and (Rp. 762.17) , order BS-02 difference (Rp.875,79) and (Rp. 1378.28) and KL-01 order difference (Rp.120,98) and (Rp. 230.76). For this type of order B-03, K-01, K-02, KP-01, KN-01, S-01, KK-01 KK-02, BS-01 and F-01 shows that the positive results means that the calculation of price the subject of an order made by larger firms compared with calculations using the full costing method. To reserve B-03 difference of Rp. 639.76 and USD. 321.60, orders K-01 difference Rp.13.518,65 and Rp. 17717.83, K-02 order difference of Rp. 7289.35 and USD. 9299.87, KP01selisih order Rp. 2585.95 and 479.97, orders KN-01selisih 20492.46 and 26492.9, orders S-01 difference Rp.612,63 and Rp. 738.88, orders KK-01selisih Rp. 6192.65 and USD. 8208.39, KK-02 order difference of Rp. 3881.35 and 5104.97, BS-01 order difference of Rp. 52.53 and 29.46 and the last F-01selisih order 3997.26 and 5301.32. From the analysis that the calculation method of the order cost the company a total cost of Rp. 714442850 , - the total selling price of Rp. 962,348,792.50 and the total profit of Rp. 247,905,942.50. While calculating the total number of full costing method a cost of Rp. 686,943,309.43, the total selling price of Rp. $956,482,248.60$ and the total profit of Rp. 269,538,939.17. From the above data it was clear that the method of calculation of the cost of an order made by larger companies Rp. 27,499,540.57, the total selling price is also greater Rp. 5,866,543.90 but the result of greater profits by using the full costing method for Rp.21.632.996,67.

\section{Conclusion}

After the authors conducted an analysis of the costs related to the pricing of goods on the CV. SAGITA GRAFIKA, it can be concluded that:

- In the case of the expenses of direct material and direct labor costs, the Company CV. SAGITA GRAFIKA already calculate in accordance with the existing theory, which is based on the needs required in doing any kind of order. However, to calculate the cost of production of the company has not calculated in accordance with the existing theory, since the company split the cost of indirect labor and overhead costs equally for each order is done during the period January 2014 to December 2014, which amounted to Rp. 11.78825 million and Rp. 3.1243 million for each order, which resulted in orders with the least amount shall bear the same load with a lot of orders, so the cost of goods produced does not reflect the actual cost price. Results of the calculation method of the company for the amount of the cost is Rp. 714442 850, -, Selling Price Rp. 962,348,792.50 and the profit made by the company Rp. $247,905,942.50$

- Calculation using the full costing method is more effective than the calculation of the cost of an order made by the company. Because in this calculation shows that the orders are of little use direct labor will bear little overhead costs, and vice versa. And apart from the volume of orders difficulty level of orders also influential, then the results of the calculation method of full costing shows there are 7 (seven) orders are orders B-01, B-02, KP-02, KP-03, U-01, BS-02 and KL-01, the calculation of cost price and the selling price is greater than the calculation of the company. However, there are 10 (ten) orders that the calculation of cost price and the selling price is less than the calculation method of the order cost companies that order B-03, K-01, K-02, KP-01, KN-01, S-01, KK 01, KK-02, BS-01, and F-01. The results of the full costing method of calculation for the amount of the cost of Rp. 686,943,309.43, -, Selling Price Rp. 956,482,248.60 and the profit made by the company Rp. $269,538,939.17$.

- Comparison of the sale price between the method of calculation of the order cost the company with the full costing method of calculation as shown above that the amount of goods more efficient with the method of calculation of full costing Rp. 27,499,540.57, the selling price of Rp. 5866543.9 and generated greater profit of Rp. 21,632,996.67

Recommendations: After conducting research and analyzing the data the authors obtained from the company, the following are suggestions that should be considered by the leadership CV.SAGITA GRAFIKA in terms of cost price calculation. To avoid loading the overhead that does not conform to the orders received, the authors suggest: 
- Based on the analysis of the calculation of the order cost CV.SAGITA GRAFIKA, it has been known that the cost of goods produced does not reflect the actual cost price. From these results do with management in making decisions setting the selling price of products mold.

- Based on the analysis of cost price calculation CV.SAGITA GRAFIKA, then the company should change their methods of calculation, the calculation of cost of the order into the calculation of the full costing method, because the amount of goods produced by the calculation method is more efficient full costing Rp. 27,499,540.57 from the calculation of the company, the selling price is more efficient Rp. 5866543.9 and corporate profits to be gained greater of Rp. 21,632,996.67.

\section{References}

Hansen \& Mowen. (2003). Manajemen Biaya, Buku I, Edisi Pertama, Salemba Empat, Jakarta.

Hansen \& Mowen. (2006). Akuntansi Manajemen, Accounting Management Jakarta: Salemba Empat.

Mardiasmo. (1994). Akuntansi Biaya: Penentuan Harga Pokok Produksi Edisi pertama. Yogyakarta.

Mulyadi. (2001). Akuntansi Manajemen Konsep, Manfaat dan Rekayasa, Edisi 3, Jakarta, Salemba Empat.

Mulyadi. (2004). Akuntansi Manajemen Konsep, Manfaat \& Rekayasa Jakarta : Salemba Empat

Mulyadi. (2005). Akuntansi Biaya, Edisi Kelima, Cetakan Ketujuh, Unit Penerbit dan Percetakan (UPP) AMP, YKPN, Yogyakarta.

Mulyadi. (2007). Sistem Akuntansi, Jakarta, Salemba Empat

Mursyidi. (2008). Akuntansi biaya: Conventional costing, just in time, dan activity-based costing. Bandung: PT Refika Aditama.

Supriyono. (2001). Akuntansi Manajemen 3: Proses Pengendalian Manajemen Edisi 1,Yogyakarta; STIE YKPN

Witjaksono, A. (2006). Akuntansi biaya, Yogyakarta: Penerbit Graha Ilmu. 